\title{
Evaluation of bupirimate against rose powdery mildew
}

\author{
N. K. Adhikary ${ }^{1}$, S. Samaddar ${ }^{1}$, I. Venkatesh $^{2}$, A. K. Dolai ${ }^{1}$, J. Tarafdar ${ }^{1}$ and S. K. \\ Bhattacharyya ${ }^{3}$ \\ ${ }^{1}$ Bidhan Chandra Krishi Viswavidyalaya, Mohanpur, Nadia - 741252 (West Bengal), INDIA \\ ${ }^{2}$ Division of Plant Pathology, Indian Council of Agricultural Research, New Delhi, INDIA \\ ${ }^{3}$ Microbiology Laboratory, Department of Botany, University of Kalyani, Nadia -741235(West Bengal), INDIA \\ *Corresponding author. E-mail: nayan.bckv@gmail.com
}

Received: December 10, 2016; Revised received: June 2, 2017; Accepted: October 7, 2017

Abstract: Bupirimate 25\% Emulsifiable concentrate (EC) was evaluated for efficacy on Sphaerotheca pannosa, the causal agent of rose powdery mildew in vivo. In this experiment Bupirimate $25 \% \mathrm{EC} 6 \mathrm{ml} / \mathrm{L}$ and $4 \mathrm{ml} / \mathrm{L}$ effectively reduced the powdery mildew infection over rest of the treatments and improved the flower yield. Moreover, application of Bupirimate $25 \% \mathrm{EC}$ at the doses of 2,4 and $6 \mathrm{ml} / \mathrm{L}$ and even at higher dose $8 \mathrm{ml} / \mathrm{L}$ did not show any phytotoxic symptoms on rose plant. Thus, Bupirimate $25 \%$ EC may be considered as compared to other fungicides.

Keywords: Bupirimate, in vivo, Powdery mildew, Rose

\section{INTRODUCTION}

Rose constitute $45 \%$ share of the total world trade in floriculture production. Worldwide, approximately 8 billion rose stems, 80 million potted plants and 220 million garden roses are sold yearly, having huge demand in both domestic and international market (Roberts et al., 2003). The production of cut flower has increased over the years to attain a production of 1,952 million flowers during 2002 to 2007 and rose ranks first in global cut flower trade (Singh, 2009). Export of floriculture products from India has reached to more than Rs. 144 crores and cut flowers contribute Rs. 40 crores to the trade with roses comprising about 90 per cent (Dadlani, 2002).

In India, west Bengal is the leading state that produced maximum number $(8,903$ lakh) of cut flowers over the last decade (Singh, 2009). The use of cut flowers in home decoration has become an integral part of living in human society, particularly in affluent countries (Nelson, 1998). In West Bengal, the area covered under Rose is about 1380 ha and production is about 1793.40 lakh buds becomes a leading export hub in the country. The main rose growing areas are Purba Medinipur, Paschim Medinipur, Howrah, Nadia, Burdwan (Durgapur- Asansol belt), Birbhum, Siliguri etc. Powdery mildew is one of the most common foliar diseases of roses. White patches of fungus growth also appear on young, green shoots, and they may coalesce and cover the entire terminal portions of the growing shoots (Agrios, 2005). The white, powdery fungal growth can be very disfiguring with repeated heavy infection, reducing plant vigor. Chemical control plays an important role in minimizing disease. Rose powdery mildew is a disease of roses caused by the fungus Sphaerotheca pannosa. Bupirimate $25 \%$ EC can control rose powdery mildew. The present study was initiated with the bio-efficacy and phytotoxicity of Bupirimate 25\% EC against Powdery mildew disease in rose.

\section{MATERIALS AND METHODS}

Two consecutive winter season trials of 2012 and 2013 were conducted for evaluation of Bupirimate $25 \%$ $\mathrm{EC}$ on rose powdery mildew in the university farm at Kalyani followed by Randomized Block Design (RBD) with four replications of each treatment. Three sprays were done at 10 days interval starting from the onset of mildew. After final spray the powdery mildew disease rating was done by using a standard scale (Randhawa and Mukhopadhyay, 1986); where $0=$ No symptom on any plant; $1=$ Small powdery specks on the leaves covering $1 \%$ or less area, $3=$ Powdery lesions small, scattered covering $1-10 \%$ of leaf area, $5=$ Powdery patches big, scattered covering $11-25 \%$ of the leaf area, $7=$ Powdery patches big, coalescing covering $26-50 \%$ of leaf area $9=$ Powdery growth covering $51 \%$ or more of leaf area. Leaf turns yellow and dry up.

The severity of powdery mildew on rose was taken one day before spray and seven days after spray. Data on the mildew severity was collected from fifteen plants per treatment replication wise and percent disease severity index (PDI) was computed (Wheeler, 1969). The mean data of the powdery mildew severity was analyzed statistically. The count of marketable cut flower was taken at each harvesting event. 


\section{RESULTS AND DISCUSSION}

Bio-efficacy of Bupirimate $25 \%$ EC on rose powdery mildew are presented in the Tables 1 and 2. Bupirimate 25\% EC@6 ml/L and $4 \mathrm{ml} / \mathrm{L}$ was effectively reduced the powdery mildew infection over rest of the treatments and improved the flower yield. The details of the results are described below.

The consecutive seasonal trials shows that, three sprays of Bupirimate 25\% EC @ $6 \mathrm{ml} / \mathrm{L}$ and $4 \mathrm{ml} / \mathrm{L}$ was effectively reduced the severity of powdery mildew as compared to the control plots as well as application of Carbendazim 50\% WP and Bupirimate 25\% EC@ $2 \mathrm{ml} / \mathrm{L}$ individually. Among the test doses Bupirimate 25\% EC@6 ml/L and $4 \mathrm{ml} / \mathrm{L}$ showed best control with three spray's programme in $1^{\text {st }}$ season trial. Final PDI was 5.74 and 6.48, respectively, which were at par with each other. The untreated control recorded highest PDI (56.48) (Table 1).

Results showed consistently in rest period of application where, it was better than earlier season and gradually improves in PDI of $4.44 @ 6$ ml/L which was almost at par with first season and relatively reflects in trials with Bupirimate 25\% EC @ 4 ml/L with PDI of 5.56 (Table 2).

The results of two season's trials indicated that Bupirimate 25\% EC@4 ml/L is good enough in context to popularize and minimize the concentration $\left(\mathrm{LC}_{50}\right)$ comparatively $6 \mathrm{ml} / \mathrm{L}$ in controlling powdery mildew disease of rose. Three sprays of Buprimate @ 6 and 4 $\mathrm{ml} / \mathrm{L}$ at 10 days interval very effectively reduced the powdery mildew disease resulted in increased healthy cut flowers of rose which has great economic importance.

Pasini et al. (1991) reported that the effect was tested of benomyl, bupirimate, didemorph, fenarimol, fenpropimorph and flusilazole on grunlouregrown rose cultivar sonia artificially inoculated with $S$. pannosa var. rosae, Flusilazole, fenpropimorph and fenarimol gave the best control.

Bupirimate has a four-ways action activity on Powdery Mildew, providing Eradicant and Protectant activity against very wide range of crop situations; mainly in pome fruits, stone fruits, berries, vine, fruiting vegetables and ornamentals (such as Roses, Begonias, Chrysanthemum). Anhydrous milk fat (AMF) and soybean oil (SBO) emulsions were evaluated for control of PM (S. pannosa var. rosae) on potted rose plants maintained in a controlled environment (Chee et al., 2011). Foliage was sprayed weekly with $\operatorname{AMF}(0.7 \% \mathrm{w} / \mathrm{v})$, $\mathrm{SBO}(2 \% \mathrm{w} / \mathrm{v})$. The AMF and SBO treatments gave significantly better disease control $(\mathrm{P}<0.0001)$. Disease control is achieved by interaction of direct protection and eradication through systemic and translaminar action. Bupirimate is apparently translocated in the plant xylem. i.e. movement occurs with the translocation stream upwards in the stem and towards the mar-
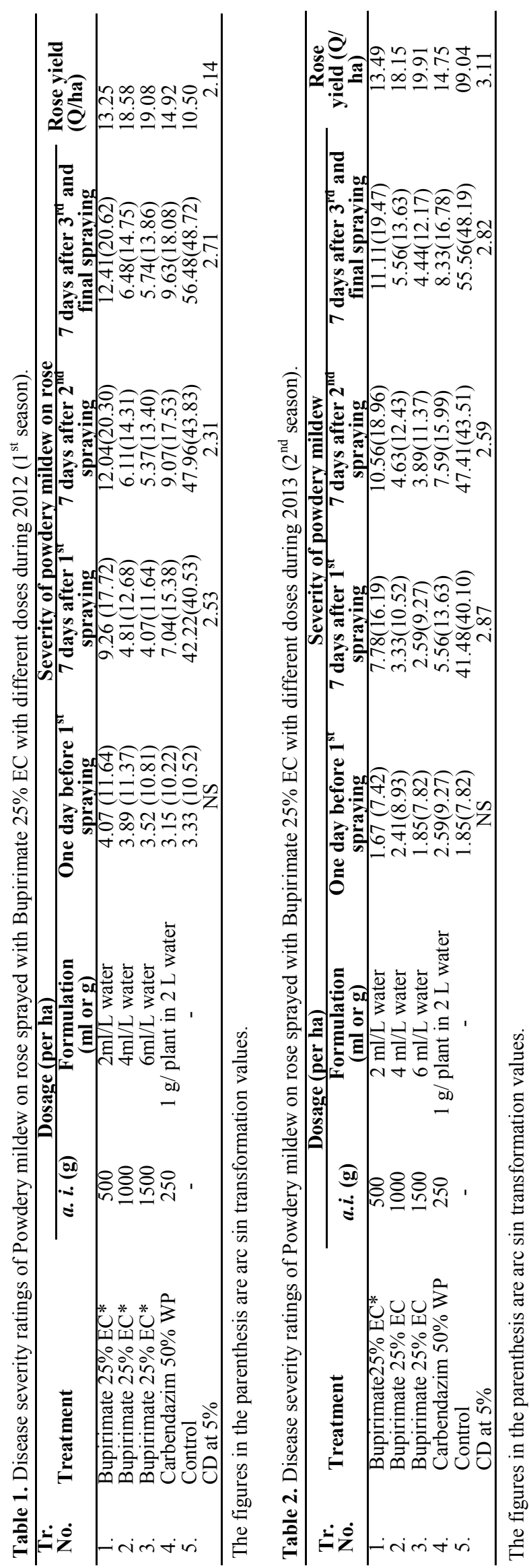
N. K. Adhikary et al. / J. Appl. \& Nat. Sci. 9 (4): 2188 - 2192 (2017)
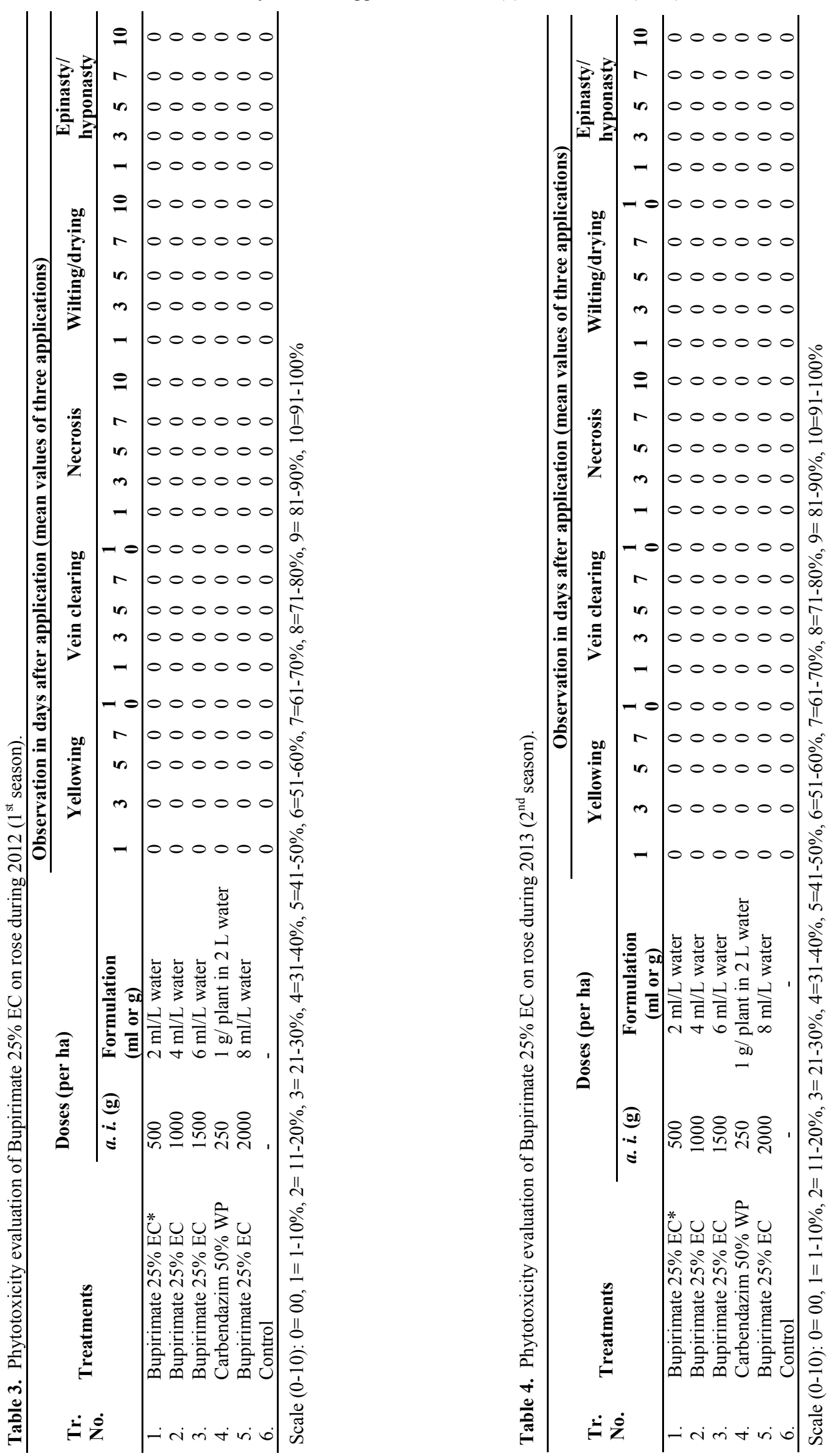
gins of leaves.

Rose yield: The data (Table 1 and 2) revealed that Bupirimate 25\% EC @ $2 \mathrm{ml} / \mathrm{L}$ in winter 2012 and 2013, improved the flower yield and flower quality. Bupirimate 25\% EC@6 ml/L given maximum yield of 19.08 and $19.91 \mathrm{Q} /$ ha respectively in winter 2012 and 2013 followed by Bupirimate 25\% EC @ $4 \mathrm{ml} / \mathrm{L}$ (18.58 and $18.15 \mathrm{Q} / \mathrm{ha}$ ) compared to control from both season (10.50 and 09.04 Q/ha).

Phytotoxicity evaluation of Buprimate: The observations on phytotoxicity of Bupirimate $25 \%$ EC are presented in Table 3 and 4.The results of two season trials revealed that Bupirimate 25\% EC @ 2, 4, 6 and $8 \mathrm{ml} / \mathrm{L}$ did not show any phytotoxicity symptoms like yellowing, Wilting, Vein clearing, Necrosis, Hyponasty and Epinasty and any other hazards on rose plant. Application of Bupirimate 25\% EC may therefore be considered as safe to rose plant. The results also justified the early works as Spray of Bupirimate 26\% EC resulted in excellent control $(96 \%)$ of rose powdery mildew (Gallian, 1982). 50\% rose powdery mildew disease control was observed by using Buprimate (Reuveni et al., 1994). Jumayli (1985) reported that the Bupirimate, Nimrod, Benlate and Thiovit were best fungicides for controlling powdery mildew disease of cucurbit under greenhouse conditions in Iraq. Mostafa et al. (1990) reported that in field trials single applications of Rubigan (Fenarimol), Byleton (Triadimefon) and Nimrod (Bupirimate) at recommended doses gave good control against E. cichoracearum, the casual organism of cucumber powdery mildew. Iqbal et al. (1994) mentioned that best control of E. cichoracearum, in greenhouse was given by spraying Pyrazophos, while Binomiyl, Carbendazim etc. Bupirimate is compatible with most of fungicides, insecticides and adjuvants, with very limited exceptions on some crops. Therefore, also form this point of view, Bupirimate should be considered a very flexible fungicide. Nimrod EW is a non-systemic fungicide specifically for control of powdery mildews, commercially known as Nimrod and it belongs to the pyrimidine as well as sulfamate group (Fact Sheet; ADAMA, New Zealand). Resistant cultivars of roses against Powdery mildew based on $\mathrm{ED}_{50}$ was selected following the method of Hijwegen et al. (1996).

Wojdyla (1999) evaluated 24 fungicides in the control of $S$. pannosa var. rosae. The treatments were performed after the first symptoms appeared and were repeated 4 times at 7 -day intervals. The best results in the control of powdery mildew were obtained with bitertanol (as Baycor 300 EC), tetraconazole (as Domark 200 EC) bupirimate (as Nimrod 250 EC), tebuconazole (as Folicur BT 225 EC), and flusilazole (as punch $400 \mathrm{EC}$ ) caused deformation of leaves after 2-3 sprayings. Menncozeb $80 \mathrm{WP}$, and triadimifon (as Bayleton 5 WP), Funaben 50 WP and myclobutanil (as Systhane MZ61, 75 WP) leaf a strong sediment on protected bushes and should not be used before flower harvest.

\section{Conclusion}

Two season trials (Winter-2012 and 2013) on Bupirimate 25\% EC@6 ml/L and $4 \mathrm{ml} / \mathrm{L}$ water were very effective in controlling powdery mildew in rose plant. Three sprayings of Bupirimate $25 \%$ EC at both the dosages of 6 and $4 \mathrm{ml} / \mathrm{L}$ water showed similar trend of efficacy against powdery mildew disease and significantly improved the flower yield and quality of rose. Moreover, application of Bupirimate 25\% EC at the doses of 2, 4, $6 \mathrm{ml} / \mathrm{L}$ water and even at higher doses 8 $\mathrm{ml} / \mathrm{L}$ water did not show any phytotoxic symptoms in rose. Therefore, spraying of Bupirimate $25 \% \mathrm{EC}$ is safe to rose plant. Considering the bio efficacy and phytotoxicity, Bupirimate 25\% EC@4 ml/L water is the optimum dose for efficiently controlling powdery mildew disease in rose plant.

\section{REFERENCES}

Agrios, G.N. (2005). Plant pathology, Fifth Edition, Department of plant pathology university of Florida, Elsevier Acadamic Press, USA, pp 1-922

Chee, A. Ah., Wurms, K.V. and George, M. (2011). Control of powdery mildew (Sphaerotheca pannosa var. rosae) on rose (Rosa L. sp.) using anhydrous milk fat and soybean oil emulsions. New Zealand Plant Prot., 64: 195200

Dadlani, N.K. (2002). Promoting floriculture business in India. Indian Hort., 46: 39-43

Gallian, J.J. (1982). Effects of volatile fungicides on Sphaerotheca pannosa on Rose, Ph.D. Thesis, Corvallis, US, pp $1-76$

Hijwegen, T., Verhaar, M.A. and Zadoks, J.C. (1996). Resistance to Sphaerotheca pannosa in roses induced by 2 , 6-dichloroisonicotinic acid. Plant Path. 45: 631-635

Iqbal, J., Maiz, M. and Saud Al-Misbah. (1994). Fungicidal control of powdery mildew of cucumber in Kuwait. Pak. J. Phytopathol., 6 (1): 65-66

Jumayli, S.A.A. (1985). Studies on powdery mildew of squash (Cucurbitapepo) and cucumber (Cucumis sativus) and its control in Nineven province (inIraq). M. Sc. Thesis in Plant Pathology, College of Agriculture and Forestry, Coll. Agric. and Forestry.Mosul University, Iraq, pp 126

Mostafa, M.S.H., Abdel-Shahid, Y.A., Ez-Eldin, I and Anwar, H.M. (1990). Factors affecting acquired resistance in Erysiphecichoracearumthe causal organism of cucumber powdery mildew. Agril. Res. Rev. 68 (3): 521-528

Nelson, V.P. (1998). Green house operation and management, $5^{\text {th }}$ edition, Pruntie hill, pp 56

Pasini, C., Awvila, D.F. and Gullino, M.H. (1991). Influence of four years of fungicide treatments on populations of Sphaerotheca pannosa var. rosae. Difesa-della-Pianete 14(1): 3-12

Randhawa, G.S. and Mukhopadhyay, A. (1986). Floriculture In India. Allied Publishers, pp 1-660

Reuveni, R., Agapov, V., Reuveni, M and Raviv, M. (1994). 
N. K. Adhikary et al. / J. Appl. \& Nat. Sci. 9 (4): 2188 - 2192 (2017)

Effects of Foliar Sprays of Phosphates on Powdery Mildew (Sphaerotheca pannosa) of Roses. J. Phytopathol. 142 (4): 131-137

Roberts, A.V., Debener, T and Gudin, S. (2003). Introduction. In: Encyclopedia of Rose Science. Oxford, U.K., pp 6-7

Singh, H.P. (2009). Floriculture Industry in India - the bright future ahead. Indian Hort., 54: 3-9

Wheeler, B.E.J. (1969). An Introduction to Plant Diseases. John Wiley publication, London, pp 301

Wojdyla, A.T. (1999). Chemical control of rose diseases. V. Effectiveness of fungicides in the control of powdery mildew on rose cv. Mercedes in greenhouse. J. Fruit and Ornamental Plant Res., 7:47-54 